ELORE (ISSN 1456-3010), vol. $16-2 / 2009$.

Julkaisija: Suomen Kansantietouden Tutkijain Seura ry.

[http://www.elore.fi/arkisto/2_09/ajank_piispanen_2_09.pdf]

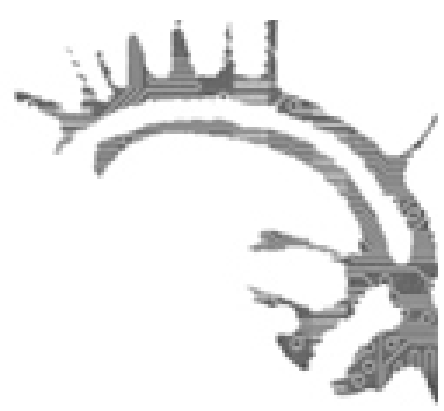

\title{
Ajankohtaista
}

\section{Kansanomainen moraAli. TUtKimus savolaisista Ja POHJALAISISTA USKOMUSTARINOISTA}

\author{
Lectio praecursoria Helsingin yliopistossa 5.6.2009
}

\section{$\underline{\text { Sirkku Piispanen }}$}

Moraali on viime aikoina ollut usein esillä erilaisissa yhteiskunnallisissa yhteyksissä. Media on välittänyt tietoja väkivaltarikoksista. Olemme lukeneet kriittisiä kannanottoja väärinkäytöksistä ja eettisesti epäilyttävistä valinnoista. Kansalaiset ovat keskuudessaan arvioineet tapahtumia.

Väkivallantekojen kohteiksi ovat joutuneet tekijöiden perheenjäsenet ja tutut tai sattumalta uhreiksi osuneet ventovieraat. Taustalla on nähty mielen sairauksia, kasaantuneita ongelmia tai selittämättömiä yhteensattumia. Eri tahojen vastuuta on perätty. Talous- ja hallintoelämän päättäjien toimet ovat herättäneet keskustelua. Optiot, bonukset ja kultaiset kädenpuristukset ovat puhuttaneet. Lahjoman antaminen liikesuhteiden edistämiseksi tai hallinnollisten etuuksien hankkimiseksi on tuomittu. Pankkikriisien maksajiksi kokevat joutuneensa syyttömät veronmaksajat. Ylikansallisten yhtiöiden voitontavoittelua eettisten päämäärien kustannuksella on moralisoitu. Rahanpesu todellisten toimien salaamiseksi on ollut esillä. Hyvä veli -verkoston on nähty vaikuttaneen virkamiesten nimityksissä. Perätään läpinäkyvyyttä poliittisten päätösten tekoon yhteisten asioiden hoitamisessa tai julkisuutta vaikkapa vaalirahoituksen taustoihin. Myös kaiken kansan lempilapsi, urheilu, on ollut usein esillä. Dopinguutisia joudumme lukemaan lähes päivittäin. Voiton, kunnian ja kasvavien rahapalkintojen tavoittelu saa jotkut turvautumaan kiellettyihin ja moraalittomiin keinoihin. Liikennekurin höltyminen näkyy päivittäin. Nopeusrajoitusten rikkominen ja punaisia valoja päin ajaminen on jatkuvaa. Aika ajoin esille tulevat rikkomukset ja laiminlyönnit lasten- tai vanhustenhuollon saralla herättävät moraalista närkästystä. Eivätkä moraalipohdinnoissa ole kirkon toimihenkilötkään jääneet vaille huomiota. 


\section{SirkKu Pisspanen}

\section{KÄSITYS OIKEASTA JA VÄÄRÄSTÄ}

Elämän ja kanssaihmisten kunnioittamista, oikeudenmukaisuutta, vastuunkantoa, rehellisyyttä ja kohtuullisuutta arvostetaan kansan moraalissa ymmärtäkseni yhä. Arvioidaan toimia yhteisten asioiden hoidossa, oman edun tavoittelussa ja huolenpidossa lähimmäisistä, siis erilaisissa arkipäivän asioissa. Toimissa saatetaan nähdä piirteitä rikoksista, rikkomuksista tai muista vääristä teoista. Aina on ihmisten yhteisö joutunut pohtimaan omia ja toistensa tekemisiä, oikeita ja vääriä.

Vaikka nykyaika on sekularisoitunut ja monimuotoistunut, elää siinä vanhan kansanuskon ja kansanmoraalin perintö. Vanhempikin tutkimusaineisto luotaa sitä, miten tähän päivään on tultu ja millaisia käsityksiä kansanomaisen moraalin perustana on. Muutokset kansan käsityksissä 1880-luvulta 2000-luvulle tultaessa vaikuttavat yllättävänkin vähäisiltä.

Osana arkipäivän tiedonvälitystä, moraalikäsitysten ylläpitoa ja arviointia toimii myös folklore, suullinen kansanperinne ja muu henkinen kansankulttuuri, jota folkloristiikka tieteenalana tutkii. Käsittelen tutkimuksessani kansanomaista moraalia savolaisten ja pohjalaisten uskomustarinoiden esille tuomana. Uskomustarinat pohjautuvat kansanuskoon ja kertovat yliluonnolliseen liittyvistä seikoista ja kokemuksista.

\section{YHTEISÖ OHJAA JÄSENIÄÄN}

Kansanuskolla tarkoitetaan ajattelussa, suullisessa kerronnassa ja tapaperinteessä eläviä käsityksiä yliluonnollisista olennoista, ilmiöistä ja tapahtumista, jotka eivät sellaisenaan kuulu virallisen tai kirkollisen uskonnon piiriin. Kansanuskossa elävät vainajat, haltiat, pyhimykset ja Kristus rinnakkain. Uskomustarinat varoittavat ja opettavat tuomalla kansanuskon ajatussisältöjä arkipäivän tilanteisiin, kuten tekee myös eteläsavolainen tarina:

\section{Yhtee talloo tul kerra reissumies ja pyytel ruokoo. Kukkaa ei vastant. Sitte mies ol kysynä kyytijä kaopuntii. Sïhe'kää ei kukkaa vastant. Sillo mies sano lähtiissaa: "No ei teillä piä mykät loppuma". Ja talo' kaik kolome lasta synt mykäks, ni on niitä mykkijä piisanna. (Mikkeli. Jaakeko Valkonen TK 111:70. 1961.)}

Tarina on tallennettu Mikkelissä vuonna 1961. Sosiaalisen tapakäyttäytymisen rikkomuksesta seuraa siinäkin rangaistus. Kansa on arvottanut ihmisten tekemisiä omalla sisäisellä moraalikoodistollaan, joka edellyttää muun muassa heikkojen auttamista. Kansan moraali on ainakin ollut laajempi kuin lainsäädäntö tai kirkolliset velvoitteet.

Kirkon oppien ja lainsäädännön lisäksi kansan moraalikäsityksiin ovat vaikuttaneet myös vuosisatoja vanhat tavat. Aiempina aikoina myös niin, että tavat ovat vaikuttaneet sekä kirkollisiin tulkintoihin että lainsäädäntöön. Tutkimuksessani olen käsitellyt asiaa myös lainkäytön kannalta. Aikalaistemme sekularisoitunut oikeustaju haluaa yhä puuttua yhteisönsä jäsenten toimiin. Vaikutussuhteet kirkollisten opetusten, tapojen ja lainsäädännön kesken ovat kuitenkin saattaneet muuttua.Tutkimusaineistoni sisäl- 
KanSANOMAINEN MORAaLI. TUTKIMUS SAVOLAISISTA JA POHJALAISISTA USKOMUSTARINOISTA

tää uskomustarinoita sadan vuoden ajalta vuodesta 1881 vuoteen 1981. Tarinoissa kerrotaan jostakin rikoksesta, rikkomuksesta tai muusta väärästä teosta ja sen yliluonnollisista seurauksista.

Kansanomaisella moraalilla tarkoitan tarinankertojien ja kuulijoiden - tavallisten ihmisten - käsityksiä oikeasta ja väärästä. Väärin tekeminen ei ole ihmisen yksityisasia. Teosta voi koitua seurauksia myös muille ihmisille ja koko yhteisölle. Sen vuoksi yhteisö kontrolloi jäsentensä käyttäytymistä. Uskomustarinoita on käytetty oikeaan käyttäytymiseen ohjaamisessa. Yhteisö on tarinoiden avulla sosiaalistanut jäseniään hyväksymiensä normien ja moraalin noudattamiseen. Erilaisissa kulttuurisissa ja sosiaalisissa konteksteissa ylläpidetään erilaisia normeja ja edellytetään erilaista moraalin noudattamista. Perinne on toisaalta universaalia, mutta toisaalta myös kulttuurisidonnaista. Perinneaiheet sopeutuvat uusiin kulttuurisiin yhteyksiin, kun ne arvioidaan ja tulkitaan uudelleen. Näin syntyy myös erilaisia uskomustarinoita.

\section{USKOMUSTARINAT JA TULKINTA MUUTTUVAT}

Kansanuskoa ja uskomustarinoita on tutkittu monista näkökulmista. Kansanuskon tutkimuksen juuret Suomessa juontavat 1700- ja 1800-luvun kansallisromantiikkaan. Uskottiin, että kansanuskoa tutkimalla löydetään tietoja kansakuntien menneisyydestä sekä tapahtuma- ja kulttuurihistoriasta. Oman kulttuurin tuntemista pidettiin tärkeänä.

Uskomustarinat tulivat tutkimuskohteeksi erityisesti 1940-luvulla. Uskomustarinoiden tutkimuksen historiaa vahvasti tiivistäen, tutkimuksen kohteena olivat aluksi tarinoissa esiintyvät yliluonnolliset olennot ja kertomusaihelmat sekä tarinoiden taustalla vallitsevat uskomukselliset käsitykset. Seuraavaksi huomio kiinnitettiin olentojen esiintymisympäristöihin ja vertailevaan tutkimukseen. Sittemmin on tutkittu muun muassa tarinoiden rakenteita, tyyppejä ja motiiveja sekä kerronnan ja tulkinnan piirteitä ja ominaisuuksia. Hyödynnän näitä omassa tutkimuksessani. Myös useita muita lähestymistapoja on käytetty, mutta kansanomaisen moraalin näkökulmaa ei tutkimuksissa kuitenkaan ole tarkasteltu. Niinpä moraalinäkökulma kansanuskon ja uskomustarinoiden tutkimukseen tuntui kiinnostavalta.

Moraalilla tarkoitetaan yleensä eron tekemistä hyvän ja pahan välillä. Siihen liitetään käsitteitä oikea, väärä, velvollisuus, kielto tai lupa. Moraalia sivuaa myös etiikan käsite, eikä käsitteitä aina eroteta toisistaan. Termien erottelussa etiikka kuitenkin tarkoittaa moraalifilosofiaa, tieteenalaa, joka tutkii moraalia. Moraali on määritelty tarkoittamaan empiirisiä ilmiöitä, yhteisöjen ja yksilöiden toimintaa ohjaavia säännöstöjä ja käytäntöjä, joita voidaan havainnoida. Moraali sisältää ne yksilön ja yhteisön arvot ja normit, joiden tavoittelu ja noudattaminen vallitsevat ihanteina yksilön tai yhteisön toiminnassa.

Arvot ja normit ovat jatkuvassa muutoksessa. Samoin ovat myös uskomustarinat ja niiden tulkinta. Tarinoiden sisällöt voivat säilyä hyvinkin pitkään, mutta tulkinta muuttuu nopeammin. Myös kertomuksen käyttöalue voi muuttua. Vanha yliluonnollisesta tapahtumasta kertova uskomustarina voi siirtyä vaikkapa kaskuksi.

Tutkimusaineistossa tulkinnan muutos näkyy ennen muuta kertojien arvioinneissa. Arvioinnit ovat 1930-luvulle saakka lähes poikkeuksetta tarinan sanomaa vahvistavia 


\section{SirkKu PiISPANen}

tai todenperäisyyttä vakuuttavia. Kertoja saattoi vahvistaa sanomaansa vakuuttamalla, että se on "totinen tosi". Myöhemmin ruvetaan kertomaan siitä, miten ennen vanhaan oli ajateltu ja uskottu. Uusimmassa, äänitearkiston aineistossa, esitetään myös epäileviä kommentteja, kuten "Mikä heissä lie perä, mutta niitä tarinoita oli”.

Tutkimuksen kannalta kertomuksen yksityiskohtien todenmukaisuuteen uskominen ei ole keskeinen seikka. Tarinaa on joka tapauksessa kerrottu tai kerrottu ennen niin uskotun ja käytetty ohjeistuksena oikeaan käyttäytymiseen.

\section{ELINKEINO, USKONELÄMÄ JA SUKUPUOLI VAIKUTTAVAT}

Tutkimusaineistoni käsittää yli 3000 Savosta ja Pohjanmaalta tallennettua tarinatoisintoa. Nämä perinnealueet valitsin tutkimuskohteiksi sen vuoksi, että alueiden historiassa ja kulttuurisissa konteksteissa on eroja. Laajimmat aineistot ovat Etelä-Savosta ja Etelä-Pohjanmaalta.

Alueilla harjoitetut elinkeinot poikkeavat toisistaan. Savo on vanhastaan kaskikulttuuri-, eränkäynti- ja järvikalastusaluetta, kun Pohjanmaalla elettiin tervanpoltolla ja peltoviljelyllä. Elinkeinot vaikuttivat myös asumistapaan ja sukupuolten väliseen työnjakoon. Pohjanmaalle syntyi aiemmin kiinteää asutusta, kun savolaiset liikkuivat kaskialueidensa myötä vielä pitkään paikasta toiseen. Pohjalainen yhteisöllisyys naapurivertailuineen ja savolainen yksilöllisyys erottuvat. Länsi-Suomessa on arvostettu varallisuutta suuresti, mutta itäsuomalaisille yleensä riitti, että pärjätään. Pohjalaisille oli tarinoiden mukaan tyypillistä tavoitella ansaitsematonta lisävarallisuutta naapurilta, kun köyhät savolaiset pyrkivät hankkimaan sitä suoraan pirulta. Savossa naiset ja miehet toimivat usein samoissa töissä, kun Pohjanmaalla työt eriytyivät naisten toimiessa jo varhemmin kotipiirissä miesten työskennellessä tervanpoltossa ja kydötyksillä. Tervanpolton loppumisella oli voimakkaita vaikutuksia pohjalaisiin yhteisöihin ja elämäntapaan. Elinkeinot ja työnjako ovat jättäneet leimansa myös uskomustarinastoon ja kansanomaiseen moraaliin.

Valtakunnan historian vaiheet näkyvät myös aineistossa. Savo joutui olemaan vuosisatoja rajamaakuntana ja jatkuvien sotien tantereena. Sodan ja rajan kirot ovat muovanneet piirteensä tarinoihin ja alueen asukkaiden ajatteluun. Alueiden henkisessä ja hengellisessä elämässä on ollut eroja. Herätysliikkeitä toimi molemmilla alueilla, mutta niiden jättämät jäljet kansanomaiseen moraaliin eroavat alueilla toisistaan. Suurimmat erot ovat havaittavissa Savon pohjois- ja eteläosien välillä. Pohjois-Savossa vallitsi Paavo Ruotsalaisen johtama suuntaus. Sïnä korostettiin jokapäiväisen parannuksen tekemistä ja ihmisen pienuuden tuntemista. Ankarin moraali tulee esille pohjoissavolaisissa tarinoissa, joissa kerrotaan kuolemaan johtaneista synneistä muita alueita yleisemmin. Etelä-Savossa puolestaan levisi suvaitsevampi noin sanottu ystäväliike. Muita alueita suurempi suvaitsevaisuus on tyypillinen eteläsavolaiselle tarinastolle.

Kansanomainen moraali on kohdellut naisia erityisen ankarasti. Ankarimmat seuraukset koituivat ruuan häpäisemisestä, vaikka naisten olisi ruuanlaittajina luullut osaavan arvostaa ruokaa ilman pelottavia varoitustarinoitakin. Naiset myös moralisoivat toisiaan ankarammin kuin miehet. Uskomustarinoista on erotettavissa lain- 
rikkomuksista sekä kristillisen tapakäyttäytymisen ja sosiaalisen tapakäyttäytymisen rikkomuksista varoittavia ohjeita. Yleisimpiä tarinoissa ovat kristillisen tapakäyttäytymisen rikkomukset kaikilla tutkimuksen perinnealueilla.

Useimmin tarinoissa esiintyvä vääristä teoista rankaisija on Etelä-Savossa piru, EteläPohjanmaalla vainaja, Pohjois-Savossa Jumala tai kummitus ja Pohjois-Pohjanmaalla vainaja tai Jumala. Rankaisijahahmot heijastavat alueilla vallinneita arvomaailmoja. Uskomustarinoiden moraaliopetusten synteesinä kansanomaisen moraali suosittaa kanssaihmisten ja muun luomakunnan kunnioittamista, kuuliaisuutta kirkolle ja uskonnolle, sekä varallisuuden kohtuullista hankkimista - samoja arvoja, jotka koetaan keskeisiksi myös tämän päivän yhteiskunnassa.

Vaikka uskomustarinat eivät nykykerronnassa saa samanlaista sijaa kuin aikaisemmin, sisältyvät niiden välittämät kansanuskon ajattelumallit toisenlaisen ilmiasun saaneina myös nykyajan arkipäiväämme. Valinta oikean ja väärän välillä säilyy tehtävänämme aina.

Filosofian tohtori Sirkku Piispanen työskentelee ja asuu Mikkelissä. 